\title{
Nuclear receptor gene polymorphisms and warfarin dose requirements in the Quebec Warfarin Cohort
}

\author{
Payman Shahabi ${ }^{1,2,3} \cdot$ Félix Lamothe ${ }^{1,2,3}$. Stéphanie Dumas ${ }^{1,2,4}$. Étienne Rouleau-Mailloux ${ }^{1,2,3}$. \\ Yassamin Feroz Zada ${ }^{1,2} \cdot$ Sylvie Provost ${ }^{1,2} \cdot$ Geraldine Asselin $^{1,2} \cdot$ Ian Mongrain ${ }^{1,2}$ - Diane Valois ${ }^{1,2}$. \\ Marie-Josée Gaulin Marion $^{1,2} \cdot$ Louis-Philippe Lemieux Perreault ${ }^{1,2} \cdot$ Sylvie Perreault ${ }^{4} \cdot$ Marie-Pierre Dubé $\mathbb{D}^{1,2,3}$
}

Received: 7 January 2017 / Revised: 24 August 2017 / Accepted: 18 September 2017 / Published online: 3 January 2018

(c) The Author(s) 2017. This article is published with open access

\begin{abstract}
Warfarin is primarily metabolized by cytochrome $2 \mathrm{C} 9$, encoded by gene $C Y P 2 C 9$. Here, we investigated whether variants in nuclear receptor genes which regulate the expression of $C Y P 2 C 9$ are associated with warfarin response. We used data from 906 warfarin users from the Quebec Warfarin Cohort (QWC) and tested the association of warfarin dose requirement at 3 months following the initiation of therapy in nine nuclear receptor genes: NRII3, NR1I2, NR3C1, ESR1, GATA4, RXRA, $V D R, C E B P A$, and HNF4A. Three correlated SNPs in the VDR gene (rs4760658, rs11168292, and rs11168293) were associated with dose requirements of warfarin $\left(P=2.68 \times 10^{-5}, P=5.81 \times 10^{-4}\right.$, and $P=5.94 \times 10^{-4}$, respectively). Required doses of warfarin were the highest for homozygotes of the minor allele at the $V D R$ variants $(P<0.0026)$. Variants in the VDR gene were associated with the variability in response to warfarin, emphasizing the possible clinical relevance of nuclear receptor gene variants on the inter-individual variability in drug metabolism.
\end{abstract}

\section{Introduction}

Despite the approval and availability of novel oral anticoagulants in recent years, warfarin still remains a commonly prescribed oral anticoagulant [1]. Optimal anticoagulation with warfarin, however, is difficult to attain owing to its narrow therapeutic window and highly complicated pharmacokinetics and pharmacodynamic profile. Moreover, there is a marked inter-individual

Electronic supplementary material The online version of this article (https://doi.org/10.1038/s41397-017-0005-1) contains supplementary material, which is available to authorized users.

Marie-Pierre Dubé

marie-pierre.dube@umontreal.ca

Sylvie Perreault

sylvie.perreault@umontreal.ca

1 Université de Montréal Beaulieu-Saucier Pharmacogenomics Centre, Montreal, QC, Canada

2 Montreal Heart Institute, Montreal, QC, Canada

3 Faculty of Medicine, Université de Montréal, Montreal, QC, Canada

4 Faculty of Pharmacy, Université de Montréal, Montreal, QC, Canada variability in response to warfarin and in the dose required to achieve the desired therapeutic effect, defined by an international normalized ratio (INR) between 2 and 3 or 2.5 and 3.5 for most indications [1]. The clinical importance of this variability is that sub-therapeutic and supra-therapeutic INRs are associated with high risk of thromboembolic and hemorrhagic events, respectively $[2,3]$. Warfarin dose requirement is influenced by numerous genetic and clinical factors [4-6]; however, genetic variation explains the largest proportion of the variability in maintenance dose among all known determinants [7]. Specifically, the genetic variants of two genes have been consistently associated with warfarin dose requirements in different populations around the world and account for up to $40 \%$ of the variation in warfarin dose requirements [6]. VKORCl is the gene encoding the warfarin target, i.e., vitamin $\mathrm{K}$ epoxide reductase complex subunit 1 and CYP2C9 is the gene encoding the main warfarin metabolizing enzyme, i.e., cytochrome $\mathrm{P}-4502 \mathrm{C} 9$.

There is accumulating evidence that the constitutive expression, as well as xenobiotic-induced transcriptional activation of human $C Y P 2 C 9$ along with other important genes in the warfarin pharmacological pathway, i.e., $C Y P 3 A 4, A B C B 1$, and epoxide hydrolase $1(E P H X 1)$, is primarily regulated through the interaction of a complex 
Table 1 Nuclear receptor genes and number of corresponding variants studied

\begin{tabular}{|c|c|c|c|c|}
\hline Genes studied & Chromosome & Target gene $^{\mathrm{a}}$ & Starting position-ending position ${ }^{\mathrm{b}}$ & $\begin{array}{l}\text { Number of variants (genotyped/imputed) } \\
(n=2423)\end{array}$ \\
\hline NR113 & 1 & $\begin{array}{l}\text { CYP } 2 C 9, C Y P 3 A 4 \\
\text { ЕРНX1 }\end{array}$ & $161199456-161208432$ & $18(4 / 14)$ \\
\hline NR1I2 & 3 & СYР2C9, СУР3А4 & $119499331-119552295$ & $93(42 / 51)$ \\
\hline$N R 3 C 1$ & 5 & СYР $2 C 9, C Y P 3 A 4$ & $142657496-143113322$ & $801(212 / 589)$ \\
\hline ESR1 & 6 & $C Y P 2 C 9$ & $152011631-152424409$ & $825(164 / 661)$ \\
\hline GATA4 & 8 & CYP2C9 & $11534433-11617510$ & $196(70 / 126)$ \\
\hline$R X R A$ & 9 & $\begin{array}{l}\text { СYР } 2 C 9, \text { СYР } 3 A 4, \\
\text { ЕРНХ1 }\end{array}$ & $137218316-137332431$ & $209(41 / 168)$ \\
\hline$V D R$ & 12 & $\begin{array}{l}\text { CYP } 2 C 9, C Y P 3 A 4, \\
A B C B 1\end{array}$ & $48235320-48298814$ & $108(54 / 54)$ \\
\hline CEBPA & 19 & CYP2C9, ЕPHX1 & $33790840-33793430$ & $4(1 / 3)$ \\
\hline$H N F 4 A$ & 20 & $\begin{array}{l}\text { СYР } 2 C 9, \text { СYР } 3 A 4, \\
\text { ЕРНХ1 }\end{array}$ & $42984441-43061485$ & $169(54 / 115)$ \\
\hline
\end{tabular}

NR1I3constitutive androstane receptor, NR1I2 pregnane X receptor, NR3C1 glucocorticoid receptor, ESR1 estrogen receptor $\alpha$, GATA4 GATA binding protein $4, R X R A$ retinoid $\mathrm{X}$ receptor alpha, $V D R$ vitamin D receptor, CEBPA CCAAT/enhancer-binding protein $\alpha, H N F 4 A$ hepatocyte nuclear factor $4 \alpha$

${ }^{\mathrm{a}}$ Ref. [8]

${ }^{\mathrm{b}}$ Based on NCBI build 37 of the human genome

network of numerous ligand-dependent nuclear receptors (NRs) with their receptor elements in the promoter region of the genes [8]. The known regulators of $C Y P 2 C 9$ expression, include: the vitamin $\mathrm{D}$ receptor $(V D R)$, pregnane $\mathrm{X}$ receptor (NR1I2), constitutive androstane receptor (NR113), retinoid $\mathrm{X}$ receptor alpha $(R X R A)$, glucocorticoid receptor $(N R 3 C l)$, estrogen receptor $\alpha(E S R l)$, hepatocyte nuclear factor $4 \alpha(H N F 4 \alpha)$, CCAAT/enhancer-binding protein $\alpha(C E B P A)$, and GATA binding protein 4 (GATA4). It has been shown that the NR proteins are encoded by polymorphic genes and that genetic variations in NR genes are potentially associated with dysregulation of the CYP2C9 gene and dysfunction of the CYP2C9 enzyme [8-11].

The influence of genetic variants in NR genes on the warfarin dose requirement has only been investigated in a limited number of studies so far [12-14] and the pharmacogenetic effects attributable to specific NRs polymorphisms have not been comprehensively explored. In light of the possible impact of the disruption of the CYP2C9 gene expression via NR on CYP2C9 enzyme activity we here aim to investigate the association of NR polymorphisms on warfarin dosing requirements. Because the role of $C Y P 2 C 9$ genetic variants on the modulation of warfarin dose has already been well established, our study presents a unique assessment of the impact of nuclear receptor polymorphisms regulating $C Y P 2 C 9$ on a clinically measurable endpoint. Here, we evaluated nine NRs with known effects on $C Y P 2 C 9$ expression for genetic association with warfarin dose requirements using a large population of incident users of warfarin from the Quebec Warfarin Cohort (QWC).

\section{Methods}

\section{Study population}

The QWC is an observational, community-based, prospective cohort of new warfarin users, which aims to study the clinical, lifestyle, and genetic determinants of response to warfarin. The recruitment period extended over 3 years, from May 2010 and July 2013 during which, 1096 participants were recruited at the Montreal Heart Institute (MHI) and 17 additional anticoagulation clinics across the Quebec province of Canada. To be eligible for inclusion, patients had to be at least 18 years of age and had to have at least one indication for warfarin therapy for an expected duration of 12 months or more. Individuals with the following criteria were excluded from the study: anticoagulation treatment with warfarin for deep vein thrombosis, pulmonary embolism or isolated left ventricular thrombosis, at least one major bleeding episode, including gastrointestinal bleeding and hemorrhagic stroke, within the past 3 months, cirrhosis and chronic hepatitis, end stage renal failure, and cognitive impairment. Following a short face-to-face recruitment interview within 2 weeks of warfarin initiation, patients were followed-up for one year with five structured 
telephone questionnaires: one at baseline which occurred up to 2 weeks after warfarin initiation, followed by three follow-up questionnaires at 3,6, and 9 months after warfarin initiation and one final questionnaire at the end of follow-up period at 12 months after warfarin initiation. At baseline, a detailed history documented data about selfreported race, demographics, education level, past medical history including cardiovascular comorbidities, tobacco and alcohol consumption, caffeine intake, level of physical activity, a dietary questionnaire, primary indication of warfarin therapy, target INR and warfarin initiation dose. Follow-up questionnaires collected data on lifestyle changes, adherence to treatment and warfarin discontinuation between the follow-up interviews. Warfarin dose requirements were reported by the patients at the follow-up interviews and were validated using hospital and pharmacy records. Patient health history was validated using governmental registry data from the RAMQ and MED-Echo in Quebec.

The study was performed under the terms of the Declaration of Helsinki. Also, the study protocol was approved by the local review boards or ethics committees and all patients gave written informed consent.

\section{Genotyping}

Genome-wide genotyping was performed at the BeaulieuSaucier Pharmacogenomics Centre, using the Illumina Infinium HumanOmni2.5-8v1.0 BeadChip (Illumina, San Diego, CA) and using the iPLEX ${ }^{\circledR}$ ADME CYP2C9/ VKORCl v1.0 Panel (Agena Inc., San Diego, CA). PyGenClean [15] version 1.2.4 and PLINK [16] version 1.07 were used for the quality checks (QC) and genetic data cleanup process. Quality control procedures included tests for deviation from Hardy-Weinberg Equilibrium, checks for sex mismatches, sample exclusion on the basis of relatedness using identity by descent testing and sample exclusion for call rate $<98 \%$ (Supplementary File 2, Table 1). We used the first two principal coordinates from multidimensional scaling (MDS) analysis performed including the study samples and HapMap references samples to identify and exclude outliers from the main Caucasian cluster. Principal component analysis was performed using EIGENSOFT [15] on study samples to enable adjustment for possible population structure with the inclusion of the first four principal components. Imputation of additional SNPs was performed using IMPUTE2 software on the basis of phase 3 data from the 1000 Genome Project. We used a cut-off of 0.90 for imputed genotype quality score and a completion rate of $98 \%$ or higher. $12,118,013$ genetic variants were imputed genome-wide and 5,699,306 (46.8\%) variants had a MAF $\geq 5 \%$. See methods in Supplementary File 2 for more details.

\section{Gene selection}

Nine NRs were selected based on the results of a literature search of the molecular mechanisms of $C Y P 2 C 9$ expression regulation: VDR, NR1I2, ESR1, RXRA, NR3C1, ESR1, $H N F 4 \alpha, C E B P A$, and GATA4. Genetic variants with a minor allele frequency (MAF) $>5 \%$ in the corresponding NR genes $(n=2423)$, as well as the common $C Y P 2 C 9$ and VKORC1 variants (CYP2C9 $* 2 \quad$ [rs1799853], *3 [rs1057910], and VKORC1 *2 [rs9923231], *3 [rs7294] and *4 [rs17708472]), were extracted from the existing QWC imputed genome-wide genotyping data. Data about the NR genes and variants studied are presented in Table 1 and in Supplementary File 1.

\section{Statistical analysis}

Statistical analyses were performed using PLINK version 1.07 and SAS ${ }^{\circledR}$ version 9.4 (SAS Institute Inc., Cary, NC). Sociodemographic, as well as clinical data are presented as mean \pm standard deviation (SD), median, and range for continuous variables or frequency (percentages) for categorical variables. Generalized linear regression modeling (GLM) of the natural $\log (\mathrm{Ln})$ transformed dose of warfarin was used to test for the additive allelic effects of the candidate SNPs on the warfarin dose requirements. Warfarin dose requirement was defined as the reported daily dose at 3 months following initiation of warfarin. Imputed genotypes were coded according to probabilities $d_{1}, d_{2}$, and $d_{3}$ (for $\mathrm{AA}, \mathrm{AB}$, and $\mathrm{BB}$ genotypes) obtained from the imputation and converted to dosage values as $D=\left[d_{1}+\left(d_{2}\right)\right.$ $2)] \times 2$, and varied between 0 and 2 . The one-degree of freedom additive genetic test was used. Univariate analysis was performed using age, sex, body mass index, smoking status, alcohol consumption (number of drinks per week), vitamin $\mathrm{K}$ intake (number of servings of vitamin K-rich foods per week) [17], baseline comorbidities (diabetes, hypertension, hyperlipidemia, and history of myocardial infarction or stroke), level of education (university, college, high school, or less), level of physical activity (inactive, light intensity, moderate intensity, hard intensity, and very hard) [18], primary indication of warfarin therapy (paroxysmal or chronic atrial fibrillation, flutter, aortic or mitral replacement and mitral stenosis) and target INR (2.0-3.0 and 2.5-3.5). We considered variables with $P<0.10$ from the univariate analysis as candidates for multivariable stepwise linear regression, and the variables with $P<0.05$ were retained for the final models. In addition to the selected covariates, we added target INR and principal components $\mathrm{C} 1-\mathrm{C} 4$ which were forced into each final model. Adjusting for principal components is a wellestablished approach to prevent from possible confounder bias due to population stratification [15]. We further 
adjusted for CYP2C9 and VKORC1 metabolizer status phenotypes, determined according to the Clinical Pharmacogenetics Implementation Consortium guideline (CPIC; https://www.pharmgkb.org), using the common CYP2C9 and VKORCl variants $(C Y P 2 C 9 * 2, * 3$ and $V K O R C 1 * 2, * 3$ and *4). Accordingly, CYP2C9 metabolizer status was defined as extensive metabolizer $(\mathrm{EM} ; * 1 / * 1)$, intermediate metabolizer (IM; $* 1 / * 2$ or $* 1 / * 3)$ and poor metabolizer (PM; $* 2 / * 2$ or $* 2 / * 3$ or $* 3 / * 3)$. VKORC1 metabolizer status was defined as high activity (HA; $* 1 / * 3$ or $* 1 / * 4$ or $* 3 / * 3$ or $* 3 / * 4$ or $* 4 / * 4$ ), intermediate activity/extensive activity (IA/EA; $* 1 / * 1$ or $* 1 / * 2$ or $* 2 / * 3$ or $* 2 / * 4$ ), and poor activity (PA; $* 2 / 2)$. The CYP2C9 and VKORC1 metabolizer status phenotypes were coded as: PM and PA: 0; IM or IA/EA: 1; and EM or HA: 2. For genetic association, a multiple-comparison adjusted significance threshold of $P<$ $8.62 \times 10^{-4}$ was calculated according to Gao et al. [19] to take into consideration the non-independence of genetic variants. We also used GLM analysis to test for the association between warfarin dose requirements among the CYP2C9/VKORC1 metabolizer status phenotypes. To compare doses among the CYP2C9 phenotypes, the model was adjusted for age, sex, C1-C4, target INR, vitamin $\mathrm{K}$ intake, and VKORC1 metabolizer status phenotypes. The same covariates were used for comparison of doses among the VKORC1 phenotypes.

GLM analysis was used to assess the association of SNP genotypes with warfarin dose, where genotypes were coded as 0,1 , and 2 according to the number of minor alleles and included in the model as a categorical variable. The genotypic model was adjusted for the same set of covariates as the allelic model. To help interpretation, mean warfarin doses are presented both as mean of Ln-transformed and as the antilog of mean of the Ln-transformed data representing the geometric mean in the original unit scale.

\section{Results}

The baseline characteristics of patients enrolled in the QWC are presented in Table 2. Of 1096 patients who were originally enrolled in the cohort, 16 patients withdrew from the study, 52 patients stopped taking warfarin within the first 3 months of treatment, 97 patients were excluded from the analyses after genetic data cleanup (Supplementary File 2, Table 1), 24 patients were excluded due to missing data, and 1 patient was categorized as an outlier. The analyses were carried out on the remaining 906 patients (Fig. 1). The mean $( \pm$ SD) of warfarin dose requirement at the 3 -month questionnaire was $4.73 \pm 2.11$ (median 4.29 ) $\mathrm{mg} /$ day with a large inter-individual variability among the study patients ranging between 0.79 and $13.21 \mathrm{mg} /$ day. Genotype
Table 2 Sociodemographic and clinical characteristics of participants from the Quebec Warfarin Cohort $(n=906)$

\begin{tabular}{|c|c|}
\hline \multicolumn{2}{|l|}{ Variable } \\
\hline \multicolumn{2}{|l|}{ Age, years $^{\mathrm{a}}$} \\
\hline Mean (SD) & $70.33(11.53$ \\
\hline Median & 72.0 \\
\hline Range & $20-96$ \\
\hline \multicolumn{2}{|l|}{ Gender, $n(\%)^{\mathrm{a}}$} \\
\hline Male & $554(61.15)$ \\
\hline Female & $352(38.85)$ \\
\hline \multicolumn{2}{|l|}{ BMI, $\left(\mathrm{kg} / \mathrm{m}^{2}\right)^{\mathrm{a}}$} \\
\hline Mean (SD) & $28.72(6.04)$ \\
\hline Median & 27.49 \\
\hline Range & $13.74-57.96$ \\
\hline \multicolumn{2}{|l|}{ Smoking status, $n(\%)$} \\
\hline Current smoker & $72(7.95)$ \\
\hline \multicolumn{2}{|l|}{ Alcohol use, no. of drinks/week ${ }^{a}$} \\
\hline Mean (SD) & $4.11(6.31)$ \\
\hline Median & 2.0 \\
\hline Range & $0-44.0$ \\
\hline \multicolumn{2}{|c|}{ Vitamin $\mathrm{K}$ intake, no. of servings of vitamin K-rich foods/week ${ }^{\mathrm{a}}$} \\
\hline Mean (SD) & $2.7(2.6)$ \\
\hline Median & 2.0 \\
\hline Range & $0.0-14.0$ \\
\hline \multicolumn{2}{|l|}{ Level of education, $n(\%)^{\mathrm{a}}$} \\
\hline University & $180(19.87)$ \\
\hline College or equivalent & $129(14.27)$ \\
\hline High school or less & $597(65.89)$ \\
\hline \multicolumn{2}{|l|}{ Level of physical activity, $n(\%)^{\mathrm{a}}$} \\
\hline Inactive & $242(26.71)$ \\
\hline Light intensity & $430(47.46)$ \\
\hline Moderate intensity & $170(18.76)$ \\
\hline Hard intensity & $23(2.54)$ \\
\hline Very hard & $20(2.21)$ \\
\hline Missing & $21(2.32)$ \\
\hline \multicolumn{2}{|l|}{ Co-morbidity, $n(\%)$} \\
\hline Hypertension $^{\mathrm{a}}$ & $621(68.54)$ \\
\hline Diabetes & $246(27.15)$ \\
\hline Hyperlipidemia $^{a}$ & $565(62.36)$ \\
\hline Myocardial infarction $^{\mathrm{a}}$ & $218(24.06)$ \\
\hline Stroke & $65(7.17)$ \\
\hline \multicolumn{2}{|c|}{ Primary indication of warfarin therapy, $n(\%)$} \\
\hline Paroxysmal atrial fibrillation $^{\mathrm{a}}$ & $371(40.95)$ \\
\hline Chronic atrial fibrillation & $304(33.55)$ \\
\hline Flutter & $101(11.15)$ \\
\hline Aortic valve replacement ${ }^{\mathrm{a}}$ & $93(10.26)$ \\
\hline Mitral valve replacement ${ }^{\mathrm{a}}$ & $48(5.30)$ \\
\hline Mitral stenosis & $10(1.10)$ \\
\hline
\end{tabular}

Target INR, $n(\%)^{\mathrm{a}}$ 
Table 2 (continued)

Variable

$2.0-3.0$

795 (87.75)

$2.5-3.5$

$111(12.25)$

INR International normalized ratio, $S D$ standard deviation

${ }^{a}$ Variables found in univariate analysis to be associated with warfarin dose $(P<0.10)$

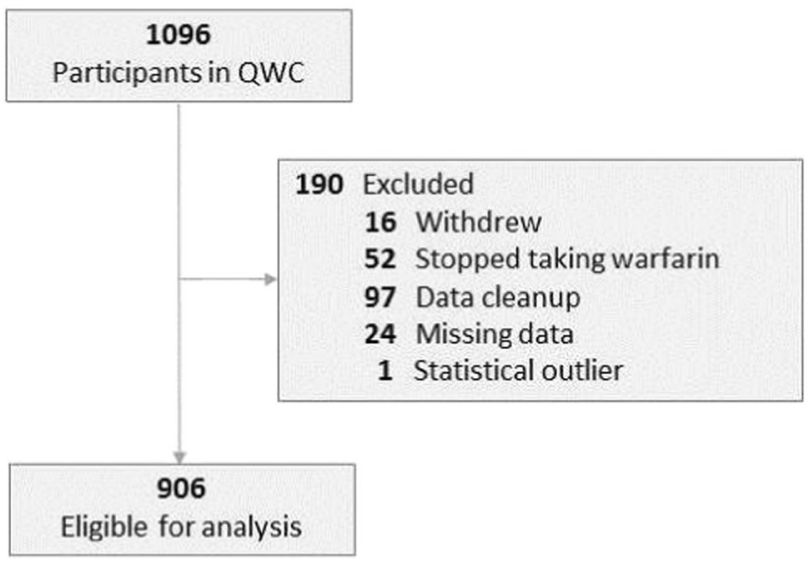

Fig. 1 Flow diagram for patient inclusion in the study

distributions for all SNPs were consistent with Hardy-Weinberg equilibrium.

Selected covariates in the prediction of warfarin dose following stepwise regression were age, with a multivariable term $\beta=-0.012$, and $P=6.3 \times 10^{-18}$, sex (being female, $\beta=-0.128, \quad P=1.21 \times 10^{-5}$ ), and vitamin $\mathrm{K}$ intake $(\beta=0.014, \quad P=0.018)$. Principal components $\mathrm{C} 1-\mathrm{C} 4$ to control for population stratification were added to the model as well as target INR which although only borderline significant, can influence target dose, as well as CYP2C9/VKORC1 metabolizer phenotypes, which are well-established predictors of warfarin dose requirements (Supplementary File 2, Table 2).

\section{Association of CYP2C9/VKORC1 SNPs and CYP2C9/ VKORC1 phenotypes with warfarin dose}

The multivariable linear regression additive genetic model for VKORC1 alleles $* 2\left(P=2.04 \times 10^{-62}\right), * 3(P=3.00 \times$ $\left.10^{-26}\right)$, and $* 4\left(P=1.27 \times 10^{-9}\right)$, as well as $C Y P 2 C 9$ alleles $* 2\left(P=2.70 \times 10^{-9}\right)$ and $* 3 \quad\left(P=7.83 \times 10^{-17}\right)$ passed our established significance threshold for association with warfarin dose requirement (Table 3 ). In addition, there was a significant difference in warfarin dose requirements among the CYP2C9 metabolizer status phenotypes $(P=$ $\left.4.10 \times 10^{-36}\right)$, so that the lowest dose of warfarin was required for PM, followed by IM and EM. Likewise, the
VKORC1 metabolizer status phenotype was significantly associated with warfarin dose requirements in multivariable regression analysis $\left(P=4.63 \times 10^{-72}\right)$, so that the lowest and highest doses of warfarin were required for PA and HA, respectively (Table 4$)$.

\section{Association of NR gene polymorphisms and warfarin dose}

The results of the linear regression additive genetic model for all selected NR gene polymorphisms are presented in Supplementary File 1. Of the 2423 SNPs studied, three $V D R$ SNPs were identified to be associated with warfarin dose: $\operatorname{rs} 11168292\left(P=5.94 \times 10^{-4}\right), \quad \operatorname{rs} 11168293(P=$ $\left.5.81 \times 10^{-4}\right)$, and rs4760658 $\left(P=2.68 \times 10^{-5}\right)($ Table 3$)$. The three VDR SNPs rs11168292, rs11168293, rs4760658 are in very tight linkage disequilibrium $\left(r^{2}>0.97\right)$. The results of the genotypic association analyses showed that there was a significant difference in warfarin dose requirements among the genotypes of the identified SNPs in the VDR $\quad(P=0.0026, \quad P=0.0025$, and $P=0.0012$ for rs11168292, rs11168293, and rs4760658, respectively), so that patients who were homozygous for the minor allele at either of the three identified SNPs, required higher doses of warfarin than heterozygotes and homozygotes of will-type alleles (Table 5). As shown in Table 5, mean warfarin doses were generally higher for homozygous carriers of the minor allele at the three VDR variants. For rs11168292, mean daily warfarin doses were $4.68,4.44$, and $4.16 \mathrm{mg}$ per day for GG, CG, and CC individuals, respectively, for rs11168293 mean daily warfarin doses were $4.65,4.44$, and $4.16 \mathrm{mg}$ per day for TT, GT, and GG individuals, respectively, and for rs4760658 mean daily warfarin doses were $4.65,4.44$, and $4.14 \mathrm{mg}$ per day for $\mathrm{GG}, \mathrm{AG}$, and AA individuals, respectively. We have also considered the association of the three $V D R$ variants with stable warfarin dose requirements at 3 months by excluding $C Y P 2 C 9$ and VKORCl activity status from the list of adjustment variables. Results show that associations are strongly maintained with rs11168292 (Beta (SE) $=0.083(0.022) ; P=$ $\left.1.26 \times 10^{-4}\right)$, rs $11168293($ Beta $(\mathrm{SE})=0.084(0.022) ; P=$ $\left.1.03 \times 10^{-4}\right)$, and rs4760658 (Beta $(\mathrm{SE})=0.088(0.022) ; P$ $=4.69 \times 10^{-5}$ ).

We have also tested for the allelic association of four out of five additional SNPs that have been previously reported in the literature [12-14] for association with warfarin dose (Table 3). No significant association was detected between warfarin dose requirements and rs 2501873 in the ESRl $(P$ $=0.486)$, rs2472682 in the NR1I2 (0.868), rs2645400 ( $P=$ $0.144)$, and $\mathrm{rs} 4841588(P=0.402)$ in GATA4. Variant rs3212198 in the HNF4A was excluded from the analyses due to a low call rate. Similarly, combinations of the mentioned SNPs were not associated with warfarin dose 


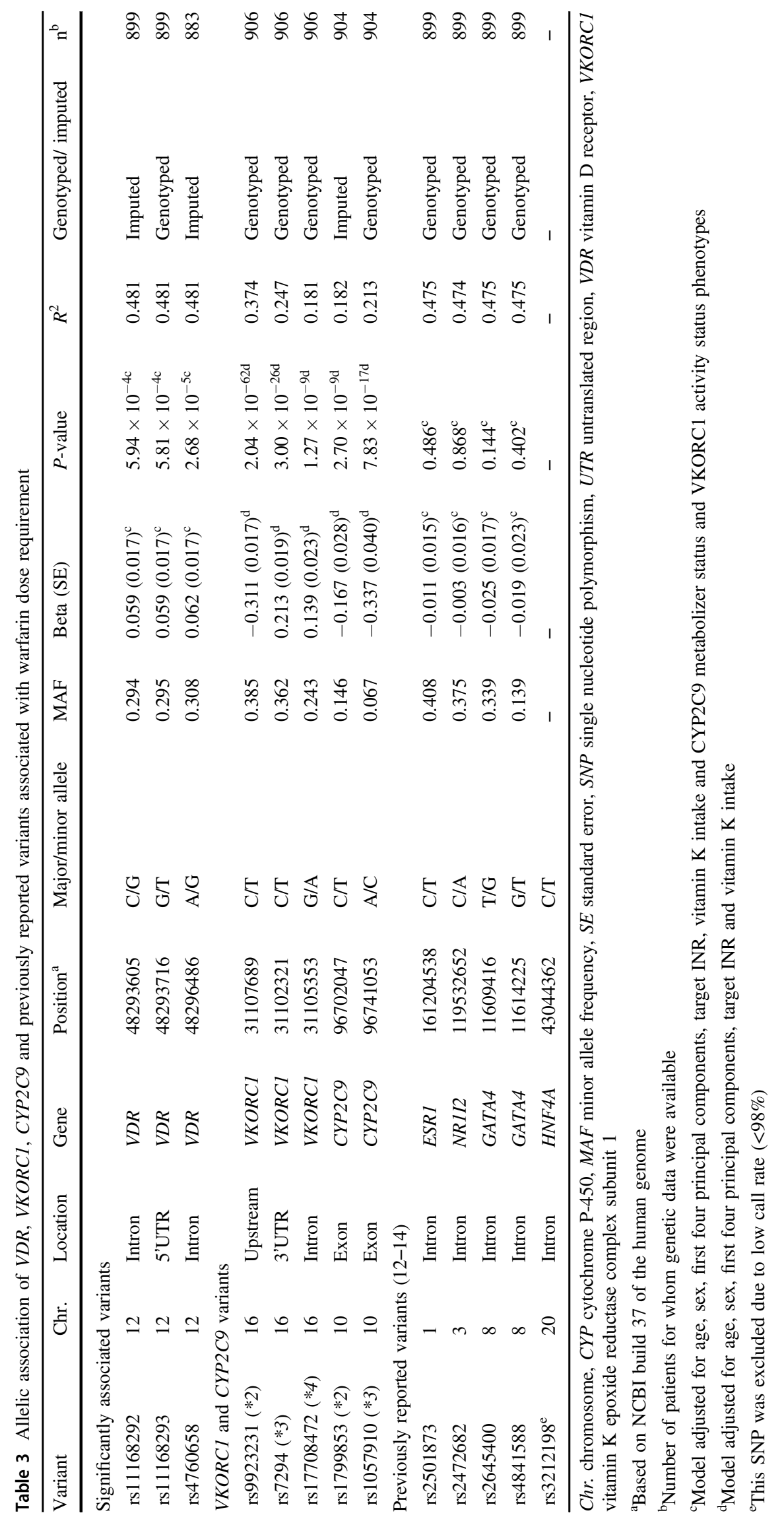


Table 4 Association results for CYP2C9 and VKORC1 metabolizer status phenotypes with warfarin dose requirement

\begin{tabular}{llllllll}
\hline & Mean dose in mg/day & $N(\%)$ & Mean dose in mg/day & $N(\%)$ & Mean dose in mg/day & $N(\%)$ & $P$-value \\
\hline CYP2C9 & PM & & IM & EM & & \\
& 2.56 & $37(4.1)$ & 3.86 & $307(34.0)$ & 4.77 & $559(61.9)$ & $4.10 \times 10^{-36 a}$ \\
VKORC1 & PA & & IA or EA & HA & \\
& 2.84 & $142(15.7)$ & 4.15 & $422(46.7)$ & 5.43 & $340(37.6)$ & $4.63 \times 10^{-72 b}$ \\
\hline
\end{tabular}

$E A$ extensive activity, $E M$ extensive metabolizer, $H A$ high activity, $I A$ intermediate activity, $I M$ intermediate metabolizer, $P A$ poor activity, $P M$ poor metabolizer, $m g$ milligram

${ }^{a}$ Genotypic model adjusted for age, sex, first four principal components, target INR, vitamin K intake and VKORC1 metabolizer status phenotypes

${ }^{\mathrm{b}}$ Genotypic model adjusted for age, sex, first four principal components, target INR, vitamin K intake, and CYP2C9 metabolizer status phenotypes

requirement (data not shown). Previously known VDR polymorphisms FokI (rs2228570; $P=0.54), \quad$ ApaI (rs7975232; $P=0.60$ ), TaqI (rs731236; $P=0.16$ ), and BsmI (rs1544410; $P=0.29$ ) did not reach statistical significance, as shown in Supplementary File 1.

\section{Discussion}

In our study, we identified three SNPs in the nuclear receptor $V D R$ gene associated with warfarin dose requirements at 3 months following initiation of therapy. To our knowledge, this is the largest prospective study to date examining the association of warfarin dose requirements focussed at variants of NR genes. This is also the most comprehensive study of its kind in that almost all NRs for which at least a functional role in the regulation of $C Y P 2 C 9$ (and other warfarin target genes) expression is known have been investigated. Our finding supports a recent report of an association between VDR polymorphisms and stable warfarin dose in patients with mechanical valves [20]. Our finding also contributes to the general understanding of the role that nuclear receptor polymorphisms can have on human drug metabolism as measured via a clinical endpoint.

The human VDR nuclear receptor, the hormone vitamin $\mathrm{D}$ (vitamin $\mathrm{D}_{3}$ or cholecalciferol) and the enzymes involved in the biosynthesis of the active form of the hormone $(1,25$ $(\mathrm{OH})_{2} \mathrm{D}_{3}$ or calcitriol), are the main components of the vitamin $\mathrm{D}$ endocrine system [21]. Beyond its wellrecognized impact on calcium and phosphate homeostasis and bone metabolism [22], the system is essential for the maintenance and regulation of diverse biological processes including cell proliferation, differentiation and apoptosis, energy metabolic pathways including insulin-like growth factor signaling, and innate immune system. Dysregulation of the vitamin D system can be associated with an increased risk of hypertension, diabetes, viral or bacterial infections and inflammation-related diseases such as cancer and atherosclerosis [21, 23]. The ligand-activated VDR can control the basal and inducible expression of several $C Y P$ genes, particularly CYP3A4, CYP2B6 and CYP2C9 [2427], as well as that of numerous additional drugmetabolizing enzymes of phase I and II of metabolism. VDR also contributes to the regulation of $A B C B 1$, a gene involved in the pharmacokinetics of warfarin $[1,8]$.

The human VDR gene (VDR) spans $100 \mathrm{~kb}$ on chromosome 12 (12q12-14) and contains two promoter regions, including six untranslated exon regions, eight coding exons, and seven introns [21]. Molecular-based epidemiological studies have identified several functional polymorphisms in the VDR [21] and have demonstrated that the variants can affect the function of the receptor by altering its affinity to vitamin D [28, 29]. VDR genetic variants have previously been associated with a number of diseases including pulmonary tuberculosis, diabetes, osteoporosis, asthma, ulcerative colitis, breast and female reproductive cancers, melanoma, systemic lupus erythematous and rheumatoid arthritis, Parkinson's disease, and coronary artery disease [30-39]. Pharmacogenetic studies have shown that VDR polymorphisms can modulate the response to a number of drugs including anti-tubercular and anti-psoriatic medications, anti-osteoporotic agents in postmenopausal women, interferon and ribavirin in patients with hepatitis $\mathrm{C}$, vitamin D supplementation, and calcitriol [40-46], as well as with statin-induced myopathy [47]. Nevertheless, the potential association between the variations in the VDR and response to warfarin therapy has never before been reported.

Our results suggest that part of the inter-individual variability in warfarin dose requirements could be explained in part by three common polymorphisms rs4760658, rs11168292, and rs11168293 in the VDR gene independently of established $C Y P 2 C 9$ and VKORCl genotypes. The three $V D R$ variants are in tight linkage disequilibrium and were found to be significantly associated with warfarin dose after 3 months of warfarin initiation such that the highest doses of warfarin were required in minor allele homozygotes, followed by heterozygotes and wild-type 
Table 5 Warfarin dose requirement according to genotypes of $V D R$ variants

\begin{tabular}{|c|c|c|c|c|c|c|c|c|}
\hline \multirow[t]{2}{*}{$V D R$ gene variant } & \multirow[t]{2}{*}{ Major/minor allele } & \multicolumn{2}{|c|}{ Homozygous major allele } & \multicolumn{2}{|l|}{ Heterozygous } & \multicolumn{2}{|c|}{ Homozygous minor allele } & \multirow[t]{2}{*}{$P$-value } \\
\hline & & Mean dose in mg & $N(\%)$ & Mean dose in mg & $N(\%)$ & Mean dose in mg & $N(\%)$ & \\
\hline rs11168292 & $\mathrm{C} / \mathrm{G}$ & 4.16 & $443(49.0)$ & 4.44 & $382(42.2)$ & 4.68 & $81(8.9)$ & $0.0026^{\mathrm{a}}$ \\
\hline rs11168293 & $\mathrm{G} / \mathrm{T}$ & 4.16 & $442(48.9)$ & 4.44 & $383(42.3)$ & 4.65 & 81 (8.9) & $0.0025^{\mathrm{a}}$ \\
\hline rs4760658 & $\mathrm{A} / \mathrm{G}$ & 4.14 & $417(46.8)$ & 4.44 & $387(43.5)$ & 4.65 & $86(9.7)$ & $0.0012^{\mathrm{a}}$ \\
\hline
\end{tabular}

SNP single nucleotide polymorphism, $V D R$ vitamin D receptor, $m g$ milligram

${ }^{\mathrm{a}}$ Genotypic association model (2-df) adjusted for age, sex, first four principal components, target INR, vitamin K intake and CYP2C9 metabolizer status and VKORC1 activity status phenotypes

homozygotes. The allele frequency of those three correlated variants varies greatly between populations, with minor allele frequencies estimated from Hapmap phase 3 data at $\sim 0.32,0.02$, and 0.13 in the European, East Asian, and African populations, respectively [48]. Variants rs11168292 and rs11168293 are involved in promoter histone marks in gastrointestinal tissues, and so is rs4760658 for an even larger number of tissues [49]. All three SNPs were previously reported to be associated for eQTL effects on the neighboring gene SLC48A1, with the minor alleles being associated with a decrease in eQTL gene expression levels (FDR $P$-values < 0.02) [50].

Given a very large body of evidence demonstrating a consistent and strong association between the common genetic variants of CYP2C9/VKORC1 and warfarin dose [1], our analyses were conducted by adjusting for CYP2C9/ VKORC1 activity status phenotypes yielded by regrouping of the $C Y P 2 C 9^{*} 1-3$ and $V K O R C 1 * 1-4$, as recommended by the CPIC. Our results on the associations of $C Y P 2 C 9 /$ VKORC1 common variants and the CYP2C9/VKORC1 phenotypes with warfarin dose were in agreement with the previous literature [1, 51], adding further support to the reliability of our data and findings.

Our results may be explained, in part, by considering that VDR is a modulator of $C Y P 2 C 9$ (also $C Y P 3 A 4$ and $A B C B 1$ ) expression, and that the $V D R$ polymorphisms could possibly modify the activity of the receptor; therefore, one could speculate that, compared with homozygotes of the wild-type allele, carriers of $V D R$ polymorphisms could have an altered warfarin metabolism and, consequently, need an altered warfarin dose. However, the results of the present study did not corroborate an association between other NRs GATA4, $E S R 1, N R 1 I 2$, and $H N F 4 \alpha$ polymorphisms and warfarin dose, suggested by Moon et al. [12, 13] and Jeong et al. [14]. Indeed, in three separate research studies performed on a single population of 201 Korean patients with prosthetic cardiac valve, they found that GATA4 variants rs 2645400 and rs4841588, rs2472682 in the NRII2, and the combination of rs2501873 in the ESRl and rs3212198 in the $H N F 4 A$, were marginally associated with warfarin dose requirements. None of those variants showed an association with warfarin dose in our cohort. The conflicting findings between those previous studies and ours may be partly attributable to different inclusion and exclusion criteria, sample sizes, and differing approaches and methods.

In the study by She et al. [52], VDR variant rs11168292 was found to be associated with postmenopausal breast cancer in European women. Moreover, in a study by Dorjgochoo et al. [53], VDR variant rs4760658 showed marginal association with breast cancer in Chinese women, but the association was lost after adjustment for covariates. Likewise, in two separate studies by Egan et al. [54] and Poynter et al. [55], rs11168293 was not associated with colon adenoma recurrence and colorectal cancer, respectively.

Our study has some limitations that should be acknowledged. First, although our results passed a preestablished significance threshold for the designed candidate gene study with NRs, our findings do not meet the stricter significance criteria for genome-wide significance thresholds. To our defense, this genetic study is the first and only candidate gene study performed with the QWC. Our attempts at a genome-wide association study with warfarin dose requirements with the 1000 QWC participants only identified previously known genes VKORC1 and CYP2C9. This is explained largely by the size of the cohort, which may not be sufficiently powered for genome-wide association, where genetic variants have more modest effects. Future genome-wide studies with the QWC data would be valued as part of consortium and meta-analysis efforts. In addition, we did not assess whether the associated VDR variants influence serum vitamin D levels and whether those can be correlated with warfarin dose, an approach that would help validate the mechanism by which the identified variants may be modulating warfarin dose requirements. We also acknowledge that, as all patients recruited in the QWC are Caucasians and primarily of French-Canadian descent, further studies would be needed to confirm whether the association of the $V D R$ variants with warfarin dose requirements can be generalized to other populations. Another limitation of our study is the lack of data on comedications, particularly for those drugs (exp. 
amiodarone) for which the interaction with warfarin is known to be significant. Although this data is in the process of being obtained from the governmental registries, it was not available at the time of analysis.

In conclusion, our findings suggest that certain $V D R$ variants are associated with warfarin dose requirements independently of the influence exerted by $C Y P 2 C 9$ and VKORC1 polymorphisms. This finding underlines the impact of polymorphisms of this nuclear receptor gene on a clinically measurable endpoint. Additional genetic association studies are needed to validate these findings before they can be considered for clinical intervention studies.

Acknowledgements The authors would like to thank all participants to the Quebec Warfarin Cohort study. The study was funded by the Canadian Institutes of Health Research and the Center of Excellence in Personalized Medicine. M.-P. Dubé received a salary award from the Fonds de Recherche du Québec Santé; P. Shahabi received a postdoctoral fellowship from the Canadian Gene Cure Foundation and the Canadian Institutes of Health Research; S. Dumas received a scholarship from the Canadian Institutes of Health Research.

\section{Compliance with ethical standards}

Conflict of interest The authors declare that they have no conflict of interest.

Open Access This article is licensed under a Creative Commons Attribution-NonCommercial-NoDerivatives 4.0 International License, which permits any non-commercial use, sharing, distribution and reproduction in any medium or format, as long as you give appropriate credit to the original author(s) and the source, and provide a link to the Creative Commons license. You do not have permission under this license to share adapted material derived from this article or parts of it. The images or other third party material in this article are included in the article's Creative Commons license, unless indicated otherwise in a credit line to the material. If material is not included in the article's Creative Commons license and your intended use is not permitted by statutory regulation or exceeds the permitted use, you will need to obtain permission directly from the copyright holder. To view a copy of this license, visit http://creativecommons.org/licenses/by-nc-nd/4.0/.

\section{References}

1. Johnson JA, Cavallari LH. Warfarin pharmacogenetics. Trends Cardiovasc Med. 2015;25:33-41.

2. Merli GJ, Tzanis G. Warfarin: what are the clinical implications of an out-of-range-therapeutic international normalized ratio? J Thromb Thrombolys. 2009;27:293-9.

3. Carnes CA. What is the role of pharmacogenetics in optimization of warfarin dosing? Trends Cardiovasc Med. 2015;25:42-3.

4. Ageno W, Gallus AS, Wittkowsky A, Crowther M, Hylek EM, Palareti G. Oral anticoagulant therapy: antithrombotic therapy and prevention of thrombosis, 9th ed: American College of Chest Physicians Evidence-Based Clinical Practice Guidelines. Chest. 2012;141(2 Suppl):e44S-e88S.

5. Wadelius M, Pirmohamed M. Pharmacogenetics of warfarin: current status and future challenges. Pharm J. 2007;7:99-111.

6. Jonas DE, McLeod HL. Genetic and clinical factors relating to warfarin dosing. Trends Pharmacol Sci. 2009;30:375-86.
7. Zineh I, Pacanowski M, Woodcock J. Pharmacogenetics and coumarin dosing-recalibrating expectations. N Engl J Med. 2013;369:2273-5.

8. Shahabi P, Siest G, Meyer UA, Visvikis-Siest S. Human cytochrome P450 epoxygenases: variability in expression and role in inflammation-related disorders. Pharmacol Ther. 2014;144:134-61.

9. Kamiyama Y, Matsubara T, Yoshinari K, Nagata K, Kamimura H, Yamazoe Y. Role of human hepatocyte nuclear factor 4alpha in the expression of drug-metabolizing enzymes and transporters in human hepatocytes assessed by use of small interfering RNA. Drug Metab Pharmacokinet. 2007;22:287-98.

10. Shi Z, Yang W, Goldstein JA, Zhang SY. Med25 is required for estrogen receptor alpha (ERalpha)-mediated regulation of human CYP2C9 expression. Biochem Pharmacol. 2014;90:425-31.

11. Mwinyi J, Nekvindova J, Cavaco I, Hofmann Y, Pedersen RS, Landman E, et al. New insights into the regulation of CYP2C9 gene expression: the role of the transcription factor GATA-4. Drug Metab Dispos. 2010;38:415-21.

12. Moon JY, Chang BC, Lee KE, Bang JS, Gwak HS. Effects of pregnane $\mathrm{X}$ receptor genetic polymorphisms on stable Warfarin doses. J Cardiovasc Pharmacol Ther. 2015;20:532-8.

13. Moon JY, Lee KE, Chang BC, Jeong E, Jeong H, Gwak HS. Combined effects of hepatocyte nuclear factor 4alpha and constitutive androstane receptor on stable warfarin doses. Pharm Genom. 2015;25:38-40.

14. Jeong E, Lee KE, Jeong H, Chang BC, Gwak HS. Impact of GATA4 variants on stable warfarin doses in patients with prosthetic heart valves. Pharm J. 2015;15:33-7.

15. Price AL, Patterson NJ, Plenge RM, Weinblatt ME, Shadick NA, Reich D. Principal components analysis corrects for stratification in genome-wide association studies. Nat Genet. 2006;38:904-9.

16. Purcell S, Neale B, Todd-Brown K, Thomas L, Ferreira MA, Bender D, et al. PLINK: a tool set for whole-genome association and population-based linkage analyses. Am J Hum Genet. 2007;81:559-5.

17. Leblanc C, Dube MP, Presse N, Dumas S, Nguyen M, RouleauMailloux E, et al. Avoidance of vitamin K-rich foods is common among Warfarin users and translates into lower usual vitamin $\mathrm{K}$ intakes. J Acad Nutr Diet. 2016;116:1000-7.

18. Taylor-Piliae RE, Norton LC, Haskell WL, Mahbouda MH, Fair $\mathrm{JM}$, Iribarren $\mathrm{C}$, et al. Validation of a new brief physical activity survey among men and women aged 60-69 years. Am J Epidemiol. 2006;164:598-606.

19. Gao X, Starmer J, Martin ER. A multiple testing correction method for genetic association studies using correlated single nucleotide polymorphisms. Genet Epidemiol. 2008;32:361-9.

20. Lee KE, Chung JE, Yi B, Cho YJ, Kim HJ, Lee GY, et al. Influence of NR3C1 and VDR polymorphisms on stable warfarin dose in patients with mechanical cardiac valves. Int J Cardiol. 2017;236:393-7.

21. Uitterlinden AG, Fang Y, Van Meurs JB, Pols HA, Van Leeuwen JP. Genetics and biology of vitamin D receptor polymorphisms. Gene. 2004;338:143-56.

22. Holick MF. Vitamin D and bone health. J Nutr. 1996;126(4 Suppl):1159s-1164ss.

23. Dusso AS. Update on the biologic role of the vitamin D endocrine system. Curr Vasc Pharmacol. 2014;12:272-7.

24. Drocourt L, Ourlin JC, Pascussi JM, Maurel P, Vilarem MJ. Expression of CYP3A4, CYP2B6, and CYP2C9 is regulated by the vitamin D receptor pathway in primary human hepatocytes. $\mathrm{J}$ Biol Chem. 2002;277:25125-32.

25. Makishima M, Lu TT, Xie W, Whitfield GK, Domoto H, Evans $\mathrm{RM}$, et al. Vitamin D receptor as an intestinal bile acid sensor. Science. 2002;296:1313-6.

26. Tirona RG, Kim RB. Nuclear receptors and drug disposition gene regulation. J Pharm Sci. 2005;94:1169-86. 
27. Pavek P, Dvorak Z. Xenobiotic-induced transcriptional regulation of xenobiotic metabolizing enzymes of the cytochrome P450 superfamily in human extrahepatic tissues. Curr Drug Metab. 2008;9:129-43.

28. Bouillon R, Carmeliet G, Daci E, Segaert S, Verstuyf A. Vitamin D metabolism and action. Osteoporos Int. 1998;8(Suppl 2): S13-S19.

29. Cai Q, Chandler JS, Wasserman RH, Kumar R, Penniston JT. Vitamin D and adaptation to dietary calcium and phosphate deficiencies increase intestinal plasma membrane calcium pump gene expression. Proc Natl Acad Sci USA. 1993;90:1345-9.

30. Lee YH, Gyu Song G. Vitamin D receptor FokI, BsmI, TaqI, ApaI, and EcoRV polymorphisms and susceptibility to melanoma: a meta-analysis. J BUON. 2015;20:235-43.

31. Narvaez CJ, Matthews D, LaPorta E, Simmons KM, Beaudin S, Welsh J. The impact of vitamin D in breast cancer: genomics, pathways, metabolism. Front Physiol. 2014;5:213.

32. Mun MJ, Kim TH, Hwang JY, Jang WC. Vitamin D receptor gene polymorphisms and the risk for female reproductive cancers: a meta-analysis. Maturitas. 2015;81:256-65.

33. Niu MY, Wang L, Xie AM. ApaI, BsmI, FokI, and TaqI polymorphisms in the vitamin D receptor gene and Parkinson's disease. Chin Med J. 2015;128:1809-14.

34. Mosaad YM, Hammad EM, Fawzy Z, Abdal Aal IA, Youssef HM, ElSaid TO, et al. Vitamin D receptor gene polymorphism as possible risk factor in rheumatoid arthritis and rheumatoid related osteoporosis. Hum Immunol. 2014;75:452-61.

35. He L, Wang M. Association of vitamin d receptor-a gene polymorphisms with coronary heart disease in Han Chinese. Int J Clin Exp Med. 2015;8:6224-9.

36. Xia SL, Yu LQ, Chen H, Hu DY, Shao XX, Guo MD, et al. Association of vitamin $\mathrm{D}$ receptor gene polymorphisms with the susceptibility to ulcerative colitis in patients from Southeast China. J Recept Signal Transduct Res. 2015;35:530-5.

37. Lee YH, Song GG. Vitamin D receptor gene FokI, TaqI, BsmI, and ApaI polymorphisms and susceptibility to pulmonary tuberculosis: a meta-analysis. Genet Mol Res. 2015;14:9118-29.

38. Carvalho C, Marinho A, Leal B, Bettencourt A, Boleixa D, Almeida I, et al. Association between vitamin D receptor (VDR) gene polymorphisms and systemic lupus erythematosus in Portuguese patients. Lupus. 2015;24:846-53.

39. Tizaoui K, Berraies A, Hamdi B, Kaabachi W, Hamzaoui K, Hamzaoui A. Association of vitamin D receptor gene polymorphisms with asthma risk: systematic review and updated metaanalysis of case-control studies. Lung. 2014;192:955-65.

40. Roth DE, Soto G, Arenas F, Bautista CT, Ortiz J, Rodriguez R, et al. Association between vitamin $\mathrm{D}$ receptor gene polymorphisms and response to treatment of pulmonary tuberculosis. J Infect Dis. 2004;190:920-7.

41. Rathored J, Sharma SK, Singh B, Banavaliker JN, Sreenivas V, Srivastava AK, et al. Risk and outcome of multidrug-resistant tuberculosis: vitamin D receptor polymorphisms and serum 25 (OH)D. Int J Tuberc Lung Dis. 2012;16:1522-8.

42. Arabi A, Zahed L, Mahfoud Z, El-Onsi L, Nabulsi M, Maalouf J, et al. Vitamin D receptor gene polymorphisms modulate the skeletal response to vitamin D supplementation in healthy girls. Bone. 2009;45:1091-7.
43. Alvarez-Hernandez D, Naves-Diaz M, Gomez-Alonso C, Coto E, Cannata-Andia JB. Tissue-specific effect of VDR gene polymorphisms on the response to calcitriol. J Nephrol. 2008;21:843-9.

44. Garcia-Martin E, Agundez JA, Maestro ML, Suarez A, Vidaurreta $\mathrm{M}$, Martinez $\mathrm{C}$, et al. Influence of vitamin D-related gene polymorphisms (CYP27B and VDR) on the response to interferon/ ribavirin therapy in chronic hepatitis C. PLoS One. 2013;8: e74764.

45. Prieto-Perez R, Cabaleiro T, Dauden E, Ochoa D, Roman M, Abad-Santos F. Pharmacogenetics of topical and systemic treatment of psoriasis. Pharmacogenomics. 2013;14:1623-4.

46. Palomba S, Numis FG, Mossetti G, Rendina D, Vuotto P, Russo $\mathrm{T}$, et al. Raloxifene administration in post-menopausal women with osteoporosis: effect of different BsmI vitamin D receptor genotypes. Hum Reprod. 2003;18:192-8.

47. Ovesjo ML, Skilving I, Bergman P, Rane A, Ekstrom L, Bjorkhem-Bergman L. Low Vitamin D levels and genetic polymorphism in the vitamin D receptor are associated with increased risk of Statin-induced myopathy. Basic Clin Pharmacol Toxicol. 2015;118:214-8.

48. International HapMap C, Frazer KA, Ballinger DG, Cox DR, Hinds DA, Stuve LL, et al. A second generation human haplotype map of over 3.1 million SNPs. Nature. 2007;449:851-1.

49. Roadmap Epigenomics C, Kundaje A, Meuleman W, Ernst J, Bilenky M, Yen A, et al. Integrative analysis of 111 reference human epigenomes. Nature. 2015;518:317-30.

50. Westra HJ, Peters MJ, Esko T, Yaghootkar H, Schurmann C, Kettunen J, et al. Systematic identification of trans eQTLs as putative drivers of known disease associations. Nat Genet. 2013;45:1238-43.

51. Johnson JA, Gong L, Whirl-Carrillo M, Gage BF, Scott SA, Stein $\mathrm{CM}$, et al. Clinical pharmacogenetics implementation consortium guidelines for CYP2C9 and VKORC1 genotypes and warfarin dosing. Clin Pharmacol Ther. 2011;90:625-9.

52. Shi J, Grundy A, Richardson H, Burstyn I, Schuetz JM, Lohrisch $\mathrm{CA}$, et al. Genetic variation in vitamin D-related genes and risk of breast cancer among women of European and East Asian descent. Tumour Biol. 2015;37:6379-87.

53. Dorjgochoo T, Delahanty R, Lu W, Long J, Cai Q, Zheng Y, et al. Common genetic variants in the vitamin D pathway including genome-wide associated variants are not associated with breast cancer risk among Chinese women. Cancer epidemiology, biomarkers \& prevention: a publication of the American Association for Cancer Research, cosponsored by the American Society of Preventive. Oncology. 2011;20:2313-6.

54. Egan JB, Thompson PA, Ashbeck EL, Conti DV, Duggan D, Hibler E, et al. Genetic polymorphisms in vitamin D receptor VDR/RXRA influence the likelihood of colon adenoma recurrence. Cancer Res. 2010;70:1496-504.

55. Poynter JN, Jacobs ET, Figueiredo JC, Lee WH, Conti DV, Campbell PT, et al. Genetic variation in the vitamin D receptor (VDR) and the vitamin D-binding protein (GC) and risk for colorectal cancer: results from the Colon Cancer Family Registry. Cancer epidemiology, biomarkers \& prevention: a publication of the American Association for Cancer Research, cosponsored by the American Society of Preventive. Oncology. 2010;19:525-36. 